\title{
Spatial distribution of Brazilian bovine taurine breeds associated with climatic, physical and socioeconomic variables
}

\author{
[Distribuição espacial de raças taurinas bovinas brasileiras associada a variáveis \\ climáticas, físicas e socioeconômicas] \\ E.P.M. Alfonzo ${ }^{1}$, C.M. McManus ${ }^{2}$, G.S. Campos ${ }^{1}$, J.V. Portes ${ }^{1}$, \\ A.H. Padilha ${ }^{1}$, V. Peripolli ${ }^{3 *}$, J. Braccini Neto ${ }^{1}$ \\ ${ }^{1}$ Universidade Federal do Rio Grande do Sul - Porto Alegre, RS \\ ${ }^{2}$ Instituto de Biologia - Universidade de Brasília - Brasília, DF \\ ${ }^{3}$ Instituto Federal Catarinense - Campus Araquari - Araquari, SC
}

\begin{abstract}
The objective of this study was to evaluate the spatial distribution of purebred Bos taurus taurus bovine breeds raised in Brazil in association with climatic, physical and socioeconomic variables. The breeds Aberdeen Angus, Ayrshire, Braford, Brangus, Charolais, Devon, Flemish, Hereford, Pinzgauer, Shorthorn and Simental were classified according to their aptitude (milk, meat or dual-purpose). They were spatialized according to their aptitude using state and municipal information. The milk breeds were found in the states of Rio Grande do Sul and Santa Catarina, while the dual-purpose breeds were found in Minas Gerais and Rio Grande do Sul states and the beef breeds were concentrated in the southern region. Only the Aberdeen Angus meat breed showed higher dispersion in other regions. Meat and dual-purpose breeds tended to be raised in regions with lower maximum temperature, average temperature, thermal amplitude and temperature-humidity index. Dual-purpose breeds were found in municipalities with high humidity and altitude, but with a low gross domestic product, little technical guidance received from cooperatives and the government, low control of diseases and parasites, as well as low use of pasture rotation systems. The spatial distribution of Brazilian bovine taurine breeds, regardless of aptitude, was related to climatic, physical and socioeconomic factors.
\end{abstract}

Keywords: adaptation, dairy, environment, meat, spatialization

\section{RESUMO}

O objetivo deste estudo foi avaliar a distribuição espacial de raças bovinas puras Bos taurus taurus criadas no Brasil, associadas a variáveis climáticas, físicas e socioeconômicas. As raças Aberdeen Angus, Ayrshire, Braford, Brangus, Charolês, Devon, Flamenga, Hereford, Pinzgauer, Shorthorn e Simental foram classificadas de acordo com sua aptidão (leite, carne ou duplo-propósito). Elas foram espacializadas de acordo com sua aptidão a partir de informações estaduais e municipais. As raças leiteiras foram encontradas nos estados do Rio Grande do Sul e de Santa Catarina, enquanto as raças de duplo-propósito foram encontradas nos estados de Minas Gerais e Rio Grande do Sul, e as raças de carne concentraram-se na região Sul. Apenas a raça de carne Aberdeen Angus apresentou maior dispersão nas demais regiões. As raças de carne e de duplo-propósito tendem a ser criadas em regiões com menores temperatura máxima, temperatura média, amplitude térmica e índice de temperatura e umidade. As raças de duplo-propósito foram encontradas em municípios com alta umidade e altitude, mas com baixo produto interno bruto, pouca orientação técnica recebida de cooperativas e do governo, baixo controle de doenças e de parasitas e baixo uso de sistema de rotação de pastagens. A distribuição espacial das raças taurinas bovinas brasileiras, independentemente da aptidão, foi relacionada a fatores climáticos, físicos e socioeconômicos.

Palavras-chave: adaptação, ambiente, carne, espacialização, leite

Recebido em 2 de outubro de 2020

Aceito em 24 de fevereiro de 2021

*Autor para correspondência (corresponding author)

E-mail: vanessa.peripolli@hotmal.com 


\section{INTRODUCTION}

There are around 998.3 million cattle distributed worldwide (Livestock..., 2017), of which 22.64\% are in Brazil. The Brazilian bovine herd developed from animals introduced by Portuguese colonizers, comprising approximately 52 beef breeds and 13 dairy breeds (Mariante et al., 2003). Due to continental extension, Brazil has several different cattle exploitation systems, with different economies, environments and climates, and these differences in systems also occur due to the wide availability of natural resources related to animal production (Ferreira et al., 2014). Environmental factors are reflected in cattle production as a whole, due to its influences on production variables and the adaptation of animals (Joost et al., 2010). When importing animals, it is sometimes unknown whether the animals will adapt to the new environment.

Thus, animals adapted to a particular environment may have their production reduced when inserted into other breeding systems due to environmental diversity or genotype-environment interaction (McManus et al., 2010). Therefore, to avoid production changes, farmers generally try to mitigate external factors such as climate, vegetation, geomorphology, nutrition, management, health, hygiene and even socioeconomic factors (Herrero et al., 2010). Cattle breeds undergo the action of several environmental factors, being the most significant of them the climate (McManus et al., 2020). However, the ambient temperature and rainfall patterns have a significant influence on the availability of pastures and feed resources throughout the year, as well as the occurrence of diseases and parasites. Therefore, environmental factors should be better studied to increase the understanding of their effects on cattle breeds' productive traits (Costa et al., 2014).

Despite its importance for production systems, there are still few studies on the geographic distribution of Bos taurus breeds (Hanotte et al., 2000; Pae et al., 2009). The analysis of environmental factors together with spatial information makes it possible to understand trends in development and concentration of production and, in this way, to have a new perspective on aspects of cattle production (Hermuche et al., 2013) and assist in the elaboration of public policies for consolidating this activity (Hermuche et al., 2012). Thus, this study's objective was to evaluate the spatial distribution of Bos taurus breeds raised in Brazil associated with climatic, physical and socioeconomic variables.

\section{MATERIAL AND METHODS}

The location of registered herds in 2013 of the Aberdeen Angus, Ayrshire, Braford, Brangus, Charolais, Devon, Flemish, Hereford, Pinzgauer, Shorthorn and Simental breeds (Figure 1) was made available by the National Herd Book Collares breeders association $\left(31^{\circ} 46^{\prime} 34^{\prime \prime} \mathrm{S}\right.$ and $52^{\circ} 21^{\prime} 34^{\prime \prime} \mathrm{W}$ at an altitude of 9 meters). Breeds were classified according to their aptitude in milk, meat or dual-purpose (Table 1).

Table 1. Breeds of cattle in Brazil, number of municipalities and number of animals, according to state and type of production

\begin{tabular}{llccc}
\multicolumn{1}{c}{ Breed } & Type & State & $\begin{array}{c}\text { Municipalities } \\
\text { Number of } \\
\text { Animals }\end{array}$ \\
\hline Aberdeen Angus & Meat & GO, MG, MS, PA,PR, RS, SC, SP & 129 & 45,004 \\
Ayrshire & Milk & RS & 1 & 32 \\
Braford & Meat & RS, SC & 9 & 29,251 \\
Brangus & Meat & RS & 10 & 17,175 \\
Charolais & Meat & PR, RS, SC & 9 & 5,177 \\
Devon & Meat & RS, SC & 6 & 4,283 \\
Flemish & Milk & SC & 1 & 50 \\
Hereford & Meat & RS, SC & 12 & 19,353 \\
Pinzgauer & Dual-purpose & MG & 1 & 8 \\
Shorthorn & Dual-purpose & RS & 1 & 236 \\
Simental & Dual-purpose & MG & 1 & 2,300 \\
\hline Total & - & 8 & 180 & 122,869 \\
\hline
\end{tabular}

Go: Goiás; MG: Minas Gerais; MS: Mato Grosso do Sul; MT: Mato Grosso; PA: Pará; PR: Paraná; RS: Rio Grande do Sul; SC: Santa Catarina. 
Climatic variables provided by Hermuche et al. (2013) were used. The climatic data included precipitation, relative humidity, temperature and temperature and humidity index (THI). The average values of precipitation were from images of the Tropical Rainfall Measuring Mission (TRMM) sensor from the years 2000 to 2010, with a spatial resolution of $0.25^{\circ}$, or approximately $27 \mathrm{~km}$, which were processed in the Envi 4.7 software. The relative humidity values were from the National Institute of Meteorology (INMET), resulting from the average of an interval of approximately 30 years of observation of 283 climatological stations distributed throughout the territory and operated by the Institute. The stations were spatialized in the ArcGis 9.3 software, and the humidity data were interpolated by the Topogrid module in the same software. The surface temperature averages correspond to 2000 to 2010, from images of the MODIS sensor, MOD11 product, being the average of the monthly surface temperature.

These averages were redesigned in the MRT software with geotif extension, Lat/Long geographic projection and Datum WGS 84. The thermal amplitude was obtained from the difference between the maximum and minimum temperatures recorded. The THI refers to the thermal comfort of the animals, combining air temperature and relative humidity. This index was calculated from Thom's equation (1959), in which $\mathrm{THI}=\mathrm{Ta}+(0.36 \times \mathrm{To})+41.5$, where, Ta was ambient temperature and To was dew point temperature. Physical variables were also provided by Hermuche et al. (2013). The physical variables used were altitude and municipal area, with the former based on data from the Shuttle Radar Topography Mission (SRTM). It consisted of the acquisition of radar data from the entire surface of the earth (except for extreme latitudes) with a resolution of 90 meters to elaborate a digital model. The area of each municipality was obtained from the Brazilian Institute of Geography and Statistics (IBGE). The average altitude per municipality was obtained on the National Aeronautics and Space Administration (NASA).

Socioeconomic data of gross domestic product (GDP), population size and human development index (HDI) were obtained from the IBGE website (ibge.gov.br). Municipal data such as number of cattle, technical guidance received from governmental, non-governmental, private sources, from the farmer himself as well as from private integrating companies, areas with family and non-family agriculture, number of establishments and areas with permanent crops, number of farms that manage diseases and parasites and pasture rotation system were obtained. The HDI was calculated as: HDI = $\sqrt[3]{\mathrm{LEI} * \mathrm{EI} * \mathrm{II}}$, where LEI was Life Expectancy Index, EI was the Education Index, and II was the Income Index. Statistical analyzes were performed using the SAS 9.4 program (Statistical Analysis System Institute, Cary, North Carolina, USA). The climatic, physical and socioeconomic variables were standardized by the SAS ${ }^{\circledR}$ STANDARD procedure, assuming an average of zero (0) and variance one (1), to minimize the problems caused by the use of different units and thus, different variances.

To determine which variables would remain in the statistical model, PROC LOGISTIC was used, using the Stepwise method weighted by the number of animals, with a minimum significance value of 0.05 and a maximum of 0.10 of output, with climatic, physical and socioeconomic data as independent variables. The animals' aptitude (type) was considered the dependent variable. The variables that remained in the model were maximum temperature (Max), thermal amplitude (Therm_amp), average temperature (A_temp), relative humidity $(\mathrm{RH})$, temperature and humidity index (THI), altitude (Alt), gross domestic product (GDP), technical guidance received from cooperatives (Coop), technical guidance received from the government (Gov), disease and parasite control (Disea_paras) and pasture rotation system (Past_rot). All selected variables were spatialized in ArcGis 10.2, with geographic projection Lat/Long and Datum WGS 84 from the Zonal Statistics tool based on vector data related to the municipalities (Censo..., 2012).

The analysis of variance was performed using PROC GLM with the breed being the source of variation. The response variables were climatic, physical and socioeconomic. A multiple binomial logistic regression was performed with PROC LOGISTIC to test the breeds' presence by their aptitude according to the climatic, physical and socioeconomic variables. Cluster analysis (PROC CLUSTER) and tree diagram (PROC TREE) were used to organize the breed information and form groups according to the similarity between 
the breeds associated with climatic, physical and socioeconomic variables.

\section{RESULTS}

The milk breeds were located in the states of Rio Grande do Sul (RS) and Santa Catarina (SC) (Figure 1). The Ayrshire was present in the municipalities of Alegrete and Uruguaiana (RS) and the Flemish breed in the municipality of Lages (SC). The dual-purpose breeds were located in the municipalities of Lagoa Dourada (Shorthorn), and Fama (Simental) in Minas Gerais state (MG) and in in the municipality of Alegrete (Pinzgauer) in Rio Grande do Sul state (Figure 1). The meat breeds were concentrated in the southern region of the country, with only the a)

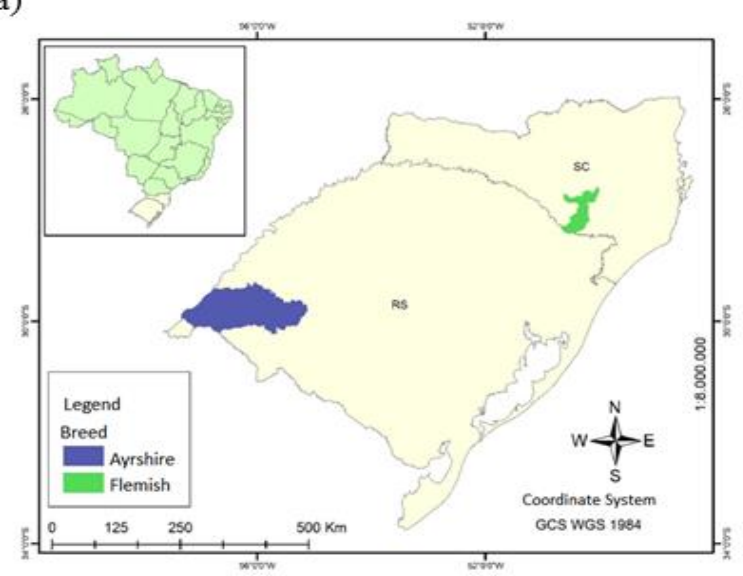

c)

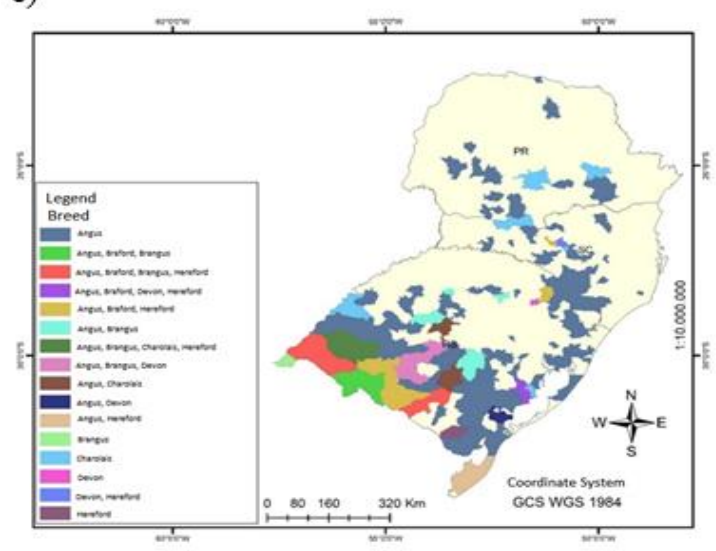

Aberdeen Angus breed spread to the other regions of the country, being found in the states of São Paulo (SP), Minas Gerais (MG), Goiás (GO) and extending to Pará (PA) (Figure 1).

Using the climatic, physical and socioeconomic variables, six breed groups were formed. The first group was formed by Angus, Braford, Brangus, Hereford, Devon and Charolais meat breeds, the second by Ayrshire milk breed, the third by Pinzgauer dual-pourpose breed, the fourth by Flemish milk breed, the fifth by Shorthorn dualpurpose breed and the last by Simental dualpurpose breed (Figure 2).

b)

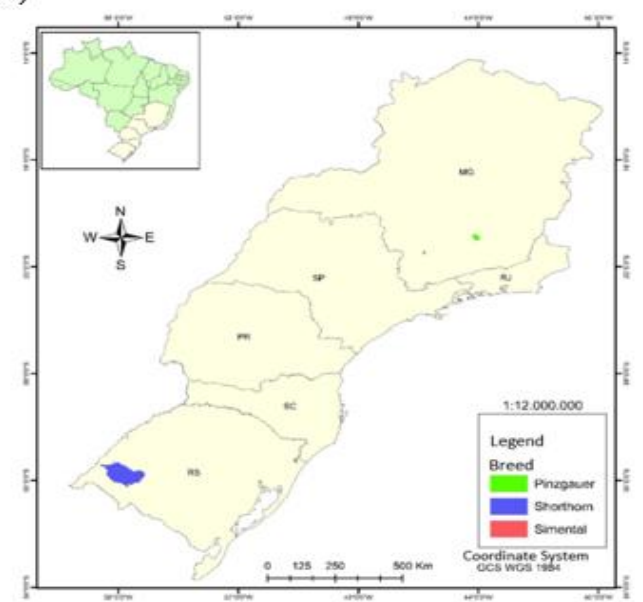

d)

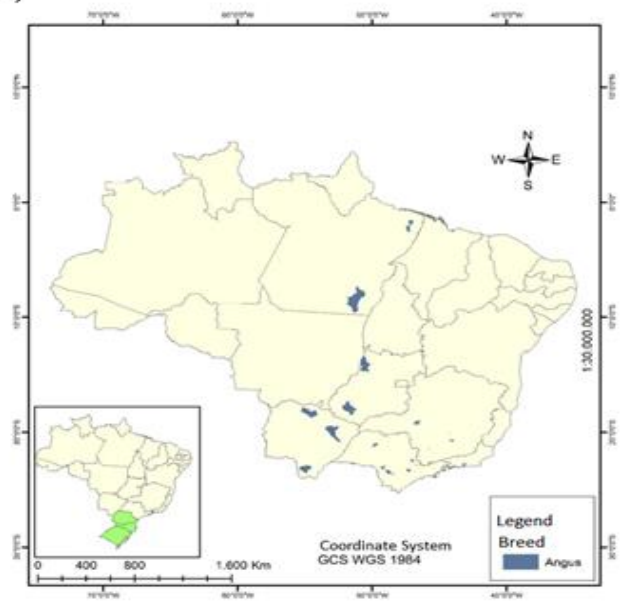

Figure 1. Spatialization of a) milk, b) dual-purpose, c) meat breeds and d) Aberdeen Angus breed in the southern and other regions of Brazil. 


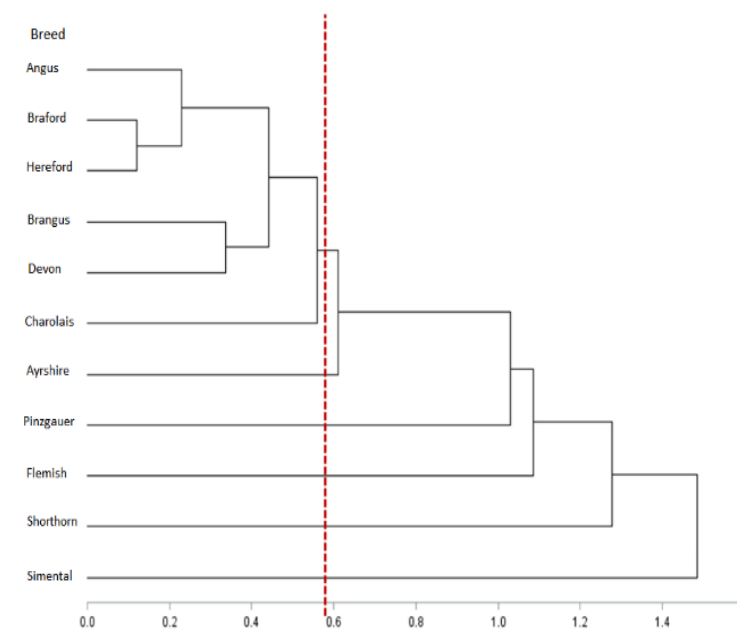

Figure 2. Tree diagram of bovine breeds in Brazil according to climatic, physical and socioeconomic variables.

Logistic regressions for the aptitude (type) of the animals (meat, dual-purpose and milk) according to climatic and physical variables demonstrated a clear difference in the probability of occurrence between the meat, dual-purpose and milk breeds. The meat (type 3) and dual-purpose (type 2) breeds tend to be raised in municipalities with lower maximum temperature, average temperature, thermal amplitude and THI, but with high humidity and altitude (Figure 3). Socioeconomic factors showed that dual-purpose breeds were raised in municipalities with a lower gross domestic product, little technical guidance received from cooperatives and integrating companies, as well as from government, low disease and parasite control, and low use of the pasture rotation system (Figure 4).

The variance analysis showed that meat and milk breeds did not vary for climatic, physical and socioeconomic variables. The Shorthorn and Simental dual-purpose breeds stood out from the others in some variables (Max, Therm_amp, RH, Coop, Disea_paras and Past_rot). Although, the Shorthorn breed was located in more stressful environments, with high values for maximum temperature (Max), average temperature (A_temp), thermal amplitude (Therm_amp) and temperature and humidity index (THI), but with better socioeconomic conditions (GDP), while the opposite occurred with the Simental breed (Table 2).

\section{DISCUSSION}

This was the first study looking at the geographical distribution of Brazilian Bos taurus breeds. The distribution of the breeds was examined according to their aptitude and climatic, physical and socioeconomic variables through logistic regression, variance and cluster analysis, determining which of these variables can contribute to a better understanding of the adaptation of different breeds to the environment, helping in the development of environmental indexes. The movement of animal production within a country or region has implications for genetics, adaptation, well-being, nutrition and production logistics, particularly for Brazil, due to its large land area (McManus et al., 2016). Most of the Brazilian herd was made up of Zebu breeds (Rebanho..., 2015), but cattle breeds of European origin predominated in the southern region.

As all breeds in this study were taurine, spatialization has shown that the meat and milk breeds were distributed in the southern region, mainly in Rio Grande do Sul (RS) (Figures 1 and 2 ). The presence of taurine meat breeds in the southern region was due to the adaptation to the temperate climate, with better carcass quality, especially marbling, tenderness and meat quality (Ferraz and Felício, 2010). The most numerous breed in this study was Aberdeen Angus, introduced in RS, and later it spread to other regions of the country. The dissemination of the Aberdeen Angus breed occurred in the 1980s. Farmers from the central and northern regions went to the South to buy animals of European breeds, mainly British, to cross with Zebu animals (Schneider, 2003). Therefore, these animals were found in the Southeast and Midwest of Brazil, due to the crossing with the Nellore breed (Vasconcellos et al., 2003) (Figure 2).

Also, the meat industry has a production base, in volume and scale, in the Midwest region (Millen et al., 2011; Meyer and Rodrigues, 2014; McManus et al., 2016), due to the intensive use of the Nellore breed. One of the reasons for the migration of cattle breeding to the Midwest and North of Brazil is the reduction of pasture areas in the South, with the advent of expanding areas for annual cultivars, such as soybeans and corn (Maranhão et al., 2019). Furthermore, the practice of deforestation in tropical areas in the North region caused an increase in the areas available for pasture (McManus et al., 2016). 

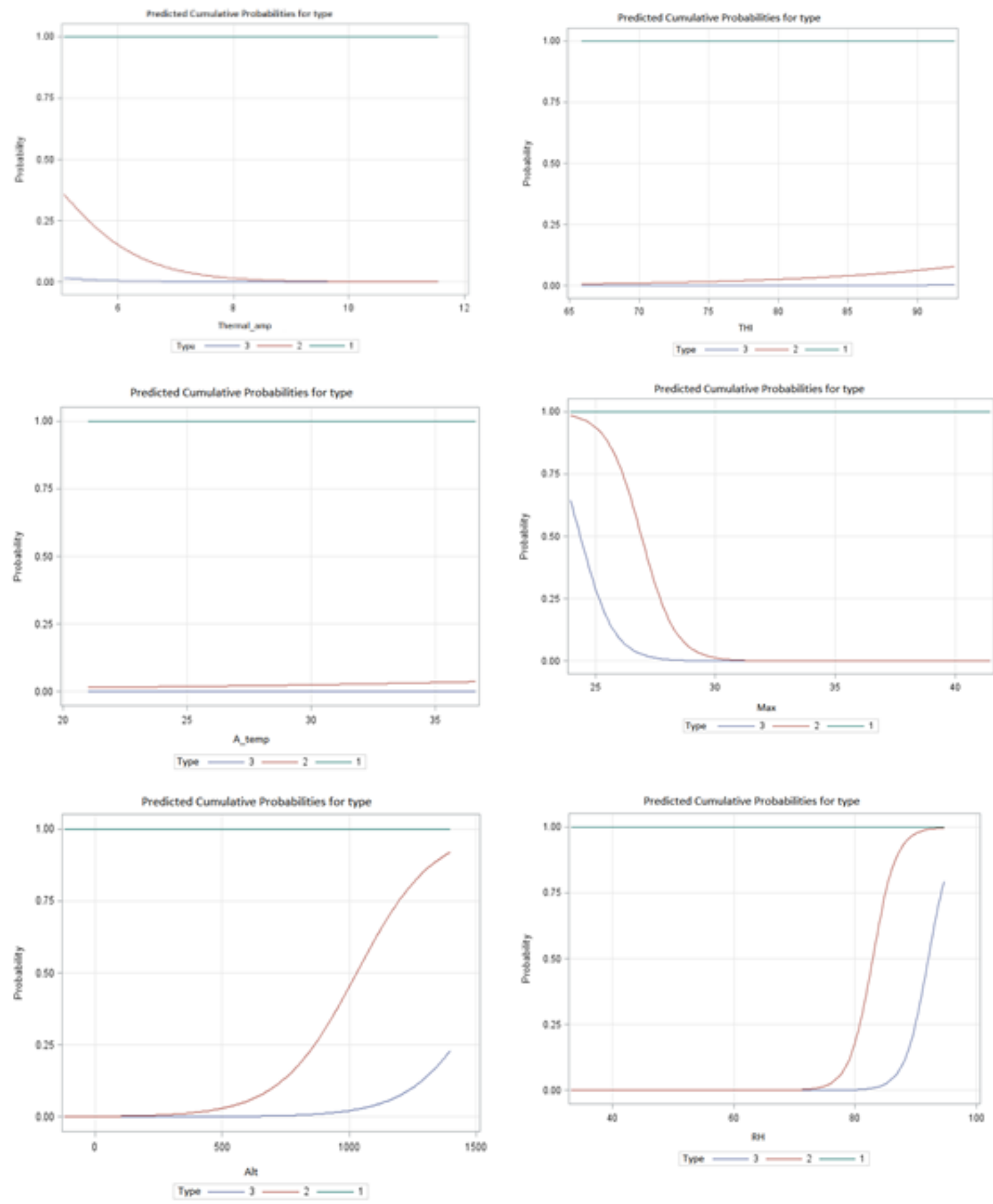

Figure 3. Logistic regression of climatic and physical variables in the distribution of cattle by meat (type 3), dual-purpose (type 2) and milk (type 1) production. (Thermal_amp - thermal amplitude; THI temperature-humidity index; A_temp - average temperature; Max- Maximum temperature; Alt - altitude; $\mathrm{RH}$ - relative humidity). 

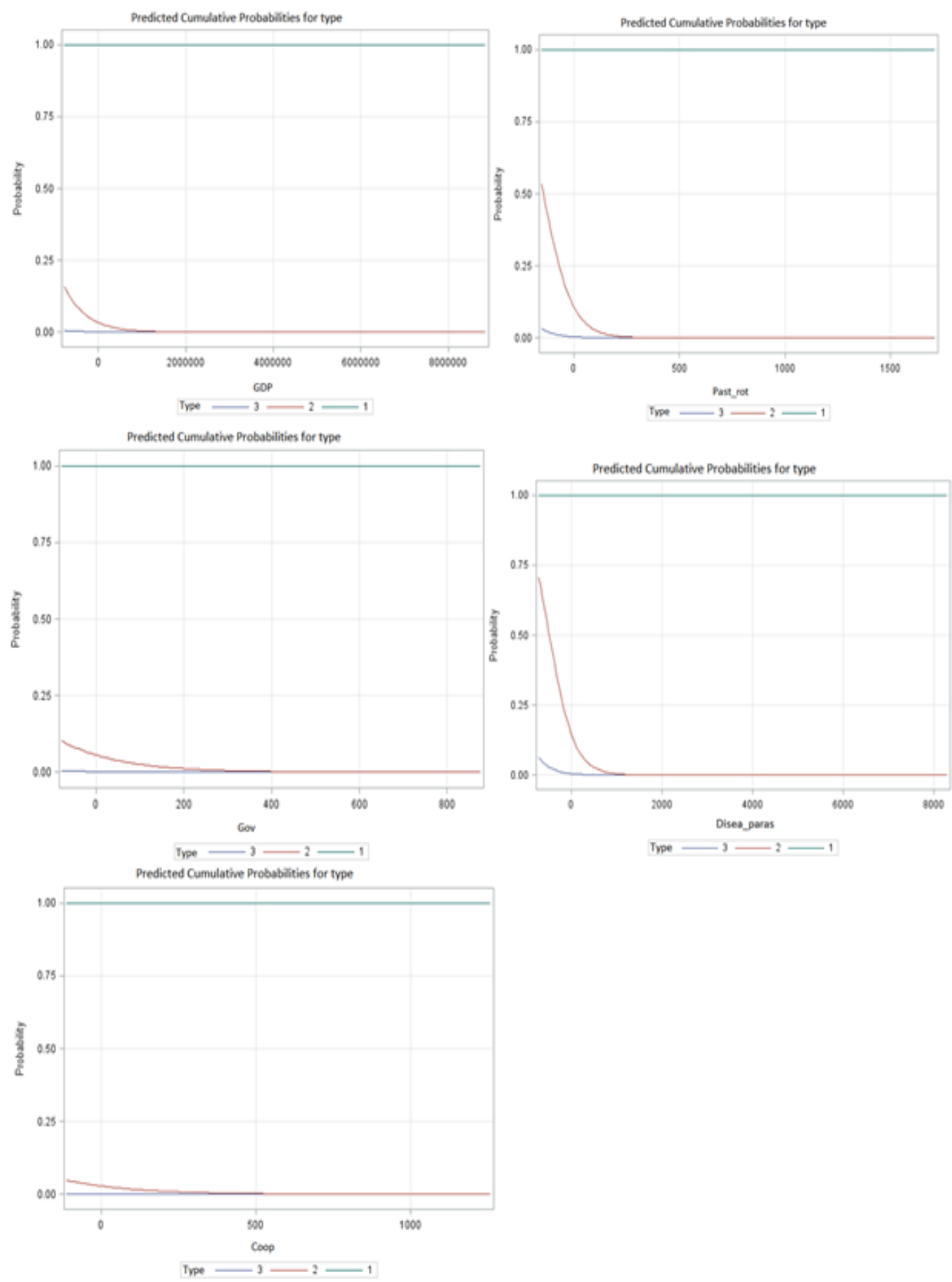

Figure 4. Logistic regression of socioeconomic variables in the distribution of cattle by meat (type 3), dualpurpose (type 2) and milk (type 1) production. (GDP - Gross Domestic Product; Past-rot - pasture rotation; Gov - governmental technical advice; Disea_paras- disease and parasite control; Coop - cooperative advice) 
Alfonzo et al.

Table 2. Averages of climatic, physical and socioeconomic variables for bovine breeds in Brazil

\begin{tabular}{|c|c|c|c|c|c|c|}
\hline \multirow{2}{*}{ Breed } & \multicolumn{6}{|c|}{ Climatic and Physical Variables } \\
\hline & Max & Therm_amp & A_temp & RH & THI & Alt \\
\hline Angus & $30.5 \pm 0.1$ & $7.8 \pm 0.0$ & $25.8 \pm 0.2$ & $66.1 \pm$ & $74.6 \pm 0.4$ & $447.8 \pm 30.5$ \\
\hline Braford & $31.0 \pm 0.7$ & $7.9 \pm 0.2$ & $26.4 \pm 0.9$ & $67.6 \pm$ & $75.6 \pm 1.5$ & $306.8 \pm 114.1$ \\
\hline Brangus & $31.2 \pm 0.6$ & $8.0 \pm 0.1$ & $26.9 \pm 0.8$ & $69.0 \pm$ & $76.5 \pm 1.3$ & $223.1 \pm 98.8$ \\
\hline Charolais & $30.0 \pm 0.6$ & $7.7 \pm 0.1$ & $26.9 \pm 0.9$ & $66.2 \pm$ & $76.2 \pm 1.4$ & $564.2 \pm 108.2$ \\
\hline Devon & $31.2 \pm 0.8$ & $8.0 \pm 0.2$ & $27.4 \pm 1.2$ & $64.6 \pm$ & $76.7 \pm 1.8$ & $351.1 \pm 139.7$ \\
\hline Hereford & $30.8 \pm 0.8$ & $7.9 \pm 0.1$ & $26.6 \pm 2.9$ & $66.9 \pm$ & $75.8 \pm 1.3$ & $343.7 \pm 98.8$ \\
\hline Pinzgauer & $28.5 \pm 2.1$ & $7.5 \pm 0.6$ & $27.2 \pm 2.9$ & $66.0 \pm$ & $77.3 \pm 4.5$ & $1,015.7 \pm 342.4$ \\
\hline Shorthorn & $31.9 \pm 2.1$ & $8.2 \pm 0.6$ & $30.5 \pm 2.9$ & $72.7 \pm$ & $82.4 \pm 4.5$ & $109.5 \pm 342.4$ \\
\hline Simental & $28.2 \pm 2.1$ & $7.4 \pm 0.6$ & $27.4 \pm 2.9$ & $85.1 \pm$ & $79.3 \pm 4.5$ & $798.1 \pm 342.4$ \\
\hline Ayrshire & $31.3 \pm 1.5$ & $8.0 \pm 0.4$ & $27.2 \pm 2.1$ & $68.0 \pm$ & $77.3 \pm 4.5$ & $100.4 \pm 342.4$ \\
\hline Flemish & $32.3 \pm 2.1$ & $8.3 \pm 0.6$ & $26.2 \pm 2.9$ & $66.0 \pm$ & $75.7 \pm 4.5$ & $981.9 \pm 342.4$ \\
\hline \multirow{2}{*}{ Breed } & \multicolumn{6}{|c|}{ Socioeconomic variables } \\
\hline & GDP & Coop & & & Disea_paras & Past_rot \\
\hline Angus & $559,646.5$ & $117.7 \pm 15.0$ & & +15.0 & $922.2 \pm 76.0$ & $230.5 \pm 17.37$ \\
\hline Braford & $675,185.2$ & $59.2 \pm 56.3$ & & \pm 40.4 & $1,135.5 \pm 284.4$ & $237.5 \pm 64.9$ \\
\hline Brangus & $474,265.7$ & $165.1 \pm 48.7$ & & \pm 34.6 & $1,291.4 \pm 246.3$ & $312.4 \pm 56.2$ \\
\hline Charolais & $979,420.3$ & $231.8 \pm 53.4$ & & +37.9 & $1,157.4 \pm 269.8$ & $272.8 \pm 61.6$ \\
\hline Devon & $299,422.6$ & $107.1 \pm 68.9$ & & \pm 49.0 & $1,446.1 \pm 348.4$ & $300.0 \pm 79.6$ \\
\hline Hereford & $492,964.0$ & $65.5 \pm 48.7$ & & \pm 34.6 & $1,043.9 \pm 246.3$ & $196.8 \pm 56.2$ \\
\hline Pinzgauer & $91,243.0$ & $4.0 \pm 168.9$ & & $=120.1$ & $543.0 \pm 853.4$ & $140.0 \pm 194.9$ \\
\hline Shorthorn & $63,736.0$ & $208.0 \pm 168.9$ & & $=120.1$ & $2,327.0 \pm 853.4$ & $368.0 \pm 194.9$ \\
\hline Simental & $27,055.0$ & $28.0 \pm 168.9$ & & 120.1 & $84.0 \pm 853.4$ & $40.0 \pm 194.9$ \\
\hline Ayrshire & $1,255,297.5$ & $111.5 \pm 119.4$ & & \pm 84.9 & $1,423.0 \pm 603.4$ & $266.5 \pm 137.8$ \\
\hline Flemish & $2,361,980.0$ & $7.0 \pm 168.9$ & 15 & 120.1 & $759.0 \pm 853.4$ & $205.0 \pm 194.9$ \\
\hline
\end{tabular}

Max: maximum temperature, Therm_amp: thermal amplitude, A_temp: average temperature, RH: relative humidity, THI: temperature and humidity index, Alt: altitude, GDP: gross domestic product, Coop: technical guidance received from cooperatives, Gov: technical guidance received from the government, Desea_paras: disease and parasite control, Past_rot: pasture rotation system.

The Simental and Shorthorn breeds were introduced in Brazil in São Paulo and Rio Grande do Sul states. After confirming these breeds' adaptation to the physical conditions, they spread to the states of Minas Gerais, Espírito Santo and Santa Catarina (Figure 1). The state of Minas Gerais centralized the two dual-purpose breeds of this study, due to their adaptation to this region. The dual-purpose system in the country's tropical regions was characterized by the use of Bos taurus taurus versus Bos taurus indicus animals (Madalena et al., 2012). These breeds combine milk production with adaptation to the climate, low-quality pastures, dry seasons, parasites and diseases (McManus et al., 2011).

Through cluster analysis (Figure 3), it was possible to form six groups, differing according to their aptitudes: meat-producing breeds (1-Angus, Braford, Brangus, Charolais, Hereford and Devon), milk-producing breeds (2-Ayrshire and 4- Flemish) and dual-purpose breed (3-Pinzgauer, 5-Shorthorn and 6-Simental). These groups were formed according to the similarity between the environment in which these breeds were raised. Thus, the differences found in a heterogeneous environment, with climate, specific physical and socioeconomic components of each region (Lopes et al., 2012), can affect breeds' distribution. Although animal production had an important relationship with the environment, this factor was not always taken into account by farmers (Silva $e t$ al., 2017). Factors such as climate, geomorphology, management, nutrition, health, socioeconomic variables and technology must be better understood so that that production can be successful (Herrero et al., 2010; Lopes et al., 2012; McManus et al., 2014).

The logistic regression showed that the milk breeds were concentrated in less stressful environments, with lower temperatures, thermal amplitude and THI (Figure 4). These breeds were concentrated in Brazil's southern region, which had areas with subtropical variables, with mild summers and cold winters, where the average temperatures were within the thermal comfort range for European dairy cattle breeds (Gabbi et 
al., 2016). This was confirmed in studies with meat (Nelore and Brangus) and milk (Holstein) breeds, which showed that animals raised in the South of Brazil obtained better performances, due to the less stressful environments (Costa et al., 2014; Santana et al., 2016).

On the other hand, the Shorthorn dual-purpose breed was concentrated in more stressful environments due to the high values of the climatic variables, while the opposite occurred with the Simental dual-purpose breed (Table 2). Both breeds were located in Minas Gerais state, where not only milk breeds were used. These areas have been used for milk production in areas for planting crops such as corn and coffee and breeding dual-purpose cattle (Guimarães et al., 2008). High altitudes characterized this region, 700 to 1,080 meters, with a Köppen climatic classification between B2 and B3 (wet). In these areas, the animals undergo some periods of thermal discomfort due to high temperatures and relative humidity (Oliveira et al., 2006) making production difficult. The production indices of dual-purpose breeds are low and concentrated in family farms that did not receive or receive little technical guidance (Figure 5 and Table 2).

This was also shown in a study in the country's Southeast, where most farms did not receive technical guidance (Paixão et al., 2015). A similar result was found by Censo... (2006), where only $22 \%$ of the investigated farms received technical guidance. In a country where the environment is heterogeneous, each of the variables studied is expressed differently depending on the region where the breeds occur. This becomes evident when comparing cattle raised in the South and those raised in the Southeast. Cattle numbers were different, which may be due to the great environmental and socioeconomic distinctions between these regions.

\section{CONCLUSIONS}

The spatial distribution of Brazilian bovine taurine breeds, regardless of aptitude, is related to climatic, physical and socioeconomic factors such as maximum temperature, average temperature, thermal amplitude, temperature and humidity index, humidity and altitude, gross domestic product, technical guidance received from cooperatives and the government, control of diseases and parasites and the use of pasture rotation system. The meat, milk and some dualpurpose (Simental and Pinzgauer) breeds were in environments more favorable to higher production levels, unlike the Shorthorn breed, which was located in a more stressful environment.

\section{ACKNOWLEDGEMENTS}

The authors wish to thank CAPES and CNPq for financing and scholarship.

\section{REFERENCES}

CENSO agropecuário. Instituto Brasileiro de Geografia e Estatística. IBGE 2012. Available in: http://www.ibge.gov.br/home/estatistica/economia/agr opecuaria/censoagro/default.shtm. Accessed in: 5 May. 2019.

CENSO agropecuário. Instituto Brasileiro de Geografia e Estatística. IBGE 2006. Available in: http://www.ibge.gov.br/home/estatistica/economia/agr opecuaria/censoagro/def ault.shtm. Accessed in: 10 Mar. 2019.

COSTA, N.S.; HERMUCHE, P.; COBUCI, J.A. et al. Georeferenced evaluation of genetic breeding value patterns in Brazilian Holstein cattle. Genet. Mol. Res., v.3, p.9806-9816, 2014.

FERRAZ, J.B.S.; FELÍCIO, P.E. Production systems an example from Brazil. Meat Sci., v.84, p.238-243, 2010.

FERREIRA, J.L.; PAIVA, S.R.; SILVA, E.C. et al. Genetic diversity and population structure of different varieties of Morada Nova hair sheep from Brazil. Genet. Mol. Res., v.13, p.2480-2490, 2014.

GABBI, A.; COBUCI, J.; FISCHER, V.; MCMANUS, C. Temporal relationship between milk production and meteorological variables in Southern Brazil. In: LEAL FILHO, W.; MUSA, H.; CAVAN, G.; O'HARE, P.; SEIXAS, J. (Eds.). Climate change adaptation, resilience and hazards. New York: Springer Publishing, 2016. p.395-408.

GUIMARÃES, A.S.; SOUZA, J.C.; ANDRADE, I.F. et al. Characterization of cattle slaughtered at the public abattoir in Lavras-MG. Ciênc. Agrotec., v.32, p.251257,2008

HANOTTE, O.; TAWAH, C.L.; BRADLEY, D.G. et $a l$. Geographic distribution and frequency of a taurine Bos taurus and an indicine Bos indicus Y specific allele amongst sub-Saharan African cattle breeds. Mol. Ecol., v.9, p.387-396, 2000 
HERMUCHE, P.M.; MARANHÃO, R.; GUIMARÃES, R. et al. Dynamics of sheep production in Brazil. Int. J. Geo-Inform., v.2, p.665-679, 2013.

HERMUCHE, P.M.; SILVA, N.C.; GUIMARÃES, R.F. et al. Dynamics of sheep production in Brazil using principal components and auto-organization features maps. Rev. Bras. Cartogr., v.64, p.821-832, 2012.

HERRERO, M.; THORNTON, P.K.; NOTENBAERT, A.M. et al. Smart investments in sustainable food production: Revisiting mixed crop-livestock systems. Sciences, v.327, p.822-825, 2010.

JOOST, S.; COLLI, L.; BARET, P.V. et al. Integrating geo-referenced multiscale and multidisciplinary data for the management of biodiversity in livestock genetic resources. Anim. Genet., v.41, p.47-63, 2010.

LIVESTOCK and products semi-annual Brazil. SemiAnnual Livestock Report 2017. USDA. Available in: http://usdabrazil.org.br/pt-br/reports/livestock-andproducts-annual.pdf. Accessed in: 2 Sep. 2020.

LOPES, F.B.; SILVA, M.C.; MIYAGI, E.S. et al. Spatialization of climate, physical and socioeconomic factors that affect the dairy goat production in Brazil and their impact on animal breeding decisions. Pesqui. Vet. Bras., v.32, p.1073-1081, 2012.

MADALENA, F.E.; PEIXOTO, M.G.C.D.; GIBSON, J. Dairy cattle genetics and its applications in Brazil. Livest. Res. Rural Dev., v.24, p.97, 2012.

MARANHÃO, R.L.A.; CARVALHO JÚNIOR, O.A.; HERMUCHE, P.M. et al. The spatiotemporal dynamics of soybean and cattle production in Brazil. Sustainability, v.11, p.1-13, 2019.

MARIANTE, A.S.; McMANUS, C.; MENDONÇA, J.F. Country report on the state of animal genetic resources. Brasília: Embrapa/Genetic Resources and Biotechnology, 2003. 121p.

McMANUS, C.; BARCELLOS, J.O.J.; FORMENTON, B.K. et al. Dynamics of cattle production in Brazil. PLoS One, v.11, p.1-15, 2016.

McMANUS, C.; LOUVANDINI, H.; CARNEIRO, H.C. et al. Production indices for dual-purpose cattle in central Brazil. Rev. Bras. Zootec., v.40, p.1576-1586. 2011.

McMANUS, C.; PAIVA, S.R.; ARAÚJO, R.O. Genetics and breeding of sheep in Brazil. Rev. Bras. Zootec., v.39, p.236-246, 2010.

McMANUS, C.M.; FARIA, D.A.; PAIVA, S.R. et al. Physiology and genetics of heat stress in cattle. $C A B$ Rev., v.15, p.1-12, 2020.
McMANUS, C.M.; HERMUCHE, P.M.; PAIVA, S.R. et al. Geographical distribution of sheep breeds in Brazil and their relationship with climatic and environmental factors as risk classification for conservation. Braz. J. Sci. Technol., v.1, p.1-15, 2014.

MEYER, P.M.; RODRIGUES, P.H.M. Progress in the Brazilian cattle industry: an analysis of the Agricultural Censuses database. Anim. Prod. Sci., v.54, p.13381344, 2014.

MILLEN, D.D.; PACHECO, R.D.L.; MEYER, P.M. et $a l$. Current outlook and future perspectives of beef production in Brazil. Anim. Front., v.1, p.46-52, 2011.

OLIVEIRA, L.M.F.; YANAGI JUNIOR, T.; FERREIRA, E. et al. Bioclimatic mapping of Southern Brazilian region for animal and human thermal comfort. Eng. Agríc., v.26, p.823-831, 2006.

PAE, T.; TAMMIKSAAR, E.; SOOVÄLI-SEPPING, H. Historical geography of estonian cattle breeds. Trames, v.13, p.357-373, 2009.

PAIXÃO, M.G.; SOUZA, G.N.; LOPES, M.A. et al. Socioeconomic and technical assistance factors related to total bacteria count and somatic cell count of milk from bulk tanks in southern Minas Gerais State, Brazil. Cienc. Rural, v.45, p.1241-1248, 2015.

REBANHO bovino brasileiro. ABIEC, 2015. Disponível em: http://www.abiec.com.br/3_rebanho.asp. Acessado em: 28 maio 2020.

SANTANA, M.L.; BIGNARDI, A.B.; ELER, J.P.; FERRAZ, J.B.S. Genetic variation of the weaning weight of beef cattle as a function of accumulated heat stress. J. Anim. Breed. Genet., v.133, p.92-104, 2016.

SCHNEIDER, S.S. More than a century in Brazil. Angus $\quad J$. 2003. Available in: http://www.angusinternational.info/pdfs/0703aj_Centu ryinBrazil.pdf 80-81/ Accessed in: 30 Jul. 2020.

SILVA, I.C.M.; BREMM, B.; TEIXEIRA, J.L. et al. Spatialization of Brazilian pig production : relationship between productive, physical, environmental, and socioeconomic variables. Trop. Anim. Health Prod., v.49, p.951-958, 2017.

THOM, E.C. The discomfort index. Weatherwise., v.12, p. 57-61, 1959.

VASCONCELLOS, L.P.M.K.; TAMBASCOTALHARI, D.; PEREIRA, A.P. et al. Genetic characterization of Aberdeen Angus cattle using molecular markers. Genet. Mol. Biol., v.26, p.133-137, 2003. 